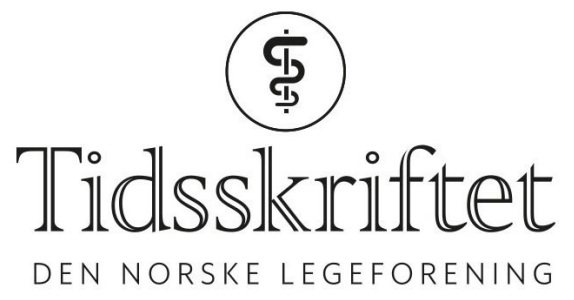

\title{
Debatten om SSRI-midlene bør omhandle hvem som har utbytte av disse
}

KOMMENTAR

\section{ULRIK FREDRIK MALT}

E-post: u.f.malt@medisin.uio.no

Ulrik Fredrik Malt er professor emeritus og overlege ved Oslo universitetssykehus. Oppgitte interessekonflikter: Forfatter har publisert en studie om effekt av antidepressiva i norsk allmennpraksis. Han har vært viseleder av Verdens Psykiaterforenings seksjon for farmakoterapi som bl.a. har skrevet en oversiktsartikkel hvor man konkluderer at SSRI har klinisk signifikant effekt ved depresjoner. Han har også vært leder av Scandinavian College of Neuropsychopharmacology. Han har frem til 2016 mottatt honorar for å forelese om ulike psykiatriske emner i møter arrangert av produsenter av legemidler. Han har og mottar fortsatt honorar for å forelese om ulike psykofarmakologiske emner i regi av ikke-kommersielle arrangører i Norge, Sverige og Tyskland.

Antidepressive legemidler har ingen klinisk meningsfull effekt, hevder M.S. Næss. Hvis noen blir bedre ved behandling med slike, er det fordi «pillene ikke fratok pasienten muligheten til å bli bedre» (1). Som støtte for sine påstander henviser han til Kirsch og medarbeideres publikasjon fra 2008 (2), der de hevder at SSRI-midler kun har en svak effekt, og da bare hos de mest deprimerte pasientene. Næss siterer ikke svenske legemyndigheter, som inspirert av Kirsch og medarbeidere, analyserer antidepressiver godkjent i Sverige og på dette grunnlag konkluderer med at SSRI-midlene - i motsetning til hva Kirsch og medarbeidere påstår - har en klinisk betydningsfull effekt (3).

Som støtte for sitt syn henviser Næss også til en dansk metaanalyse (4). Forfatterne av denne finner at SSRI-midler er bedre enn placebo, men tolker forskjellene som små. Men Næss omtaler ikke studiens metodeproblemer. De viktigste er kanskje at forfatterne ikke vekter studier ut fra kvalitet og definerer effekt kun ut fra effektstørrelser $>0,5$ basert på reduksjon av skåren på en global skala for depresjon (Hamiltons skala). Men pasienter og klinikere er opptatt av global bedring som er langt mer enn en sumskår på en skala. Global bedring er blant annet relatert til effekt på nøkkelsymptomer, for eksempel pessimistiske tanker, depressive symptomer og initiativløshet samt søvn. Totalskår på Hamiltons skala er ikke så relevant, utover at myndigheter bruker 50 \% reduksjon som kriterium for å akseptere effekt. HAM-D måler dessuten ikke én dimensjon og heller ikke nødvendigvis samme dimensjon i løpet av en behandling (5). Næss' og andres ensidige vektlegging av en globalskår er således utdatert (6) og misvisende som eneste kriterium for klinisk effekt.

Betydningen av reduksjon i totalskår versus effekt på nøkkelsymptomer kan illustreres ved henvisning til den norske randomiserte og placebokontrollerte undersøkelsen av SSRImidler brukt i allmennpraksis (hvor prosjektleder ble lønnet av Universitetet i Oslo, Oslo 
universitetssykehus og forskerne, ikke firmaet, eier data og publiserte disse). Forskjellen $\mathrm{i}$ reduksjon i en graderingsskala for depresjon (MADRS' skala) mellom SSRI-midler og placebo var 2,4 (7) hvilket ifølge Næss' kilder ikke er relevant klinisk effekt. Men effektstørrelsene av SSRI-midlene i forhold placebo var o,59 for søvn og o,54 for pessimistiske tanker, hvilket er klinisk relevant ifølge de samme kilder. Effektstørrelsene var for øvrig o,47 for selvrapportert depresjon og o,36 for initiativløshet (8). Tar man i betraktning at mange av pasientene kun hadde subterskeldepresjoner, ifølge DSM-IV, er dette effektstørrelser av klinisk betydning.

Næss skriver også at ifølge det digitale oppslagsverket UpToDate tilskrives den lille fordelen i favør av antidepressiver over placebo blant deprimerte pasienter delvis uspesifikke kliniske effekter av placebobehandling. Det kan for en leser forstås dit hen at UpToDate deler Næss' syn på at SSRI-midler ikke har klinisk signifikant effekt ved depresjoner. Det stemmer ikke. UpToDate oppsummerer slik: «Antidepressants have demonstrated efficacy for major depression in patients treated by primary care clinicians", og de anbefaler SSRImidler som et aktuelt behandlingsalternativ for depresjoner (9).

Næss gjør ellers et nummer av at mange industrisponsrede studier i de senere år har vist manglende effekt, uten at han drøfter mulige årsaker til dette. Foruten pasientutvalg kan én årsak være svak reliabilitet. Mens vi i den norske undersøkelsen kun aksepterte behandlere som oppnådde høy reliabilitet ved vurdering av depresjoner ved hjelp av MADRS' skala (ICC $\geq 0,7$ ), er det i de fleste industrisponsede studier ikke lagt inn slike krav. En amerikansk analyse av de best designede unders $ø$ kelsene sponset av National Institute of Mental Health (NIMH), hvor blant annet høy interbedømmerreliabilitet er påkrevd, fant en sterk effekt av SSRI-midler brukt til behandling hos unge med depresjoner, mens man i industrisponsrede studier ikke har funnet effekt (10).

Man kan også få inntrykk av at Næss mener at manglende publisering av negative studier er noe som kun gjelder psykofarmakologistudier sponset av industrien. Det er ikke riktig. Antallet negative psykoterapistudier som ikke blir publisert er like stor (11).

Min vurdering er at debatten om hvorvidt SSRI-midler har kliniske effekter, ikke lenger er meningsfull. Det viktigste for oss som behandler depresjoner er å vite hvem som kan ha nytte av disse mot depresjoner, hvem som blir bra kun med støtte og problemløsningsstrategier eller hvem som kan bli bra med spesifikk psykoterapi.

LITTERATUR:

1. Næss MS. Hjelper antidepressiver mot depresjon? Tidsskr Nor Legeforen 2017; 137: 606.

[PubMed][CrossRef]

2. Kirsch I, Deacon BJ, Huedo-Medina TB et al. Initial severity and antidepressant benefits: a metaanalysis of data submitted to the Food and Drug Administration. PLoS Med 2008; 5: e45.

[PubMed][CrossRef]

3. Melander H, Salmonson T, Abadie E et al. A regulatory Apologia-a review of placebo-controlled studies in regulatory submissions of new-generation antidepressants. Eur Neuropsychopharmacol 2008; 18: 623 - 7. [PubMed][CrossRef]

4. Jakobsen JC, Katakam KK, Schou A et al. Selective serotonin reuptake inhibitors versus placebo in patients with major depressive disorder. A systematic review with meta-analysis and Trial Sequential Analysis. BMC Psychiatry 2017; 17: 58. [PubMed][CrossRef]

5. Fried EI, van Borkulo CD, Epskamp S et al. Measuring depression over time ... Or not? Lack of unidimensionality and longitudinal measurement invariance in four common rating scales of depression. Psychol Assess 2016; 28: 1354 - 67. [PubMed][CrossRef]

6. Fried EI, Boschloo L, van Borkulo CD et al. Commentary: "Consistent Superiority of Selective Serotonin Reuptake Inhibitors Over Placebo in Reducing Depressed Mood in Patients with Major Depression”. Front Psychiatry 2015; 6: 117. [PubMed][CrossRef] 
7. Malt UF, Robak OH, Madsbu H-P et al. The Norwegian naturalistic treatment study of depression in general practice (NORDEP)-I: randomised double blind study. BMJ 1999; 318: 1180 - 4.

[PubMed][CrossRef]

8. Malt UF. The antidepressant debate continues. Br J Psychiatry 2002; 181: 531 - , author reply 531.

[PubMed][CrossRef]

9. Uptodate.com. 2017. Uptodate.com.

https://www.uptodate.com/contents/unipolar-depression-in-adult-primary-care-patients-and-generalmedical-illness-evidence-for-the-efficacy-of-initial-treatments?sourcesee_link (9.5.2017).

10. Walkup JT. Antidepressant efficacy for depression in children and adolescents: Industry- and NIMH-funded studies. Am J Psychiatry 2017; 174: 430 - 7. [PubMed][CrossRef]

11. Driessen E, Hollon SD, Bockting CL et al. Does publication bias inflate the apparent efficacy of psychological treatment for major depressive disorder? A systematic review and meta-analysis of US National Institutes of Health-Funded trials. PLoS One 2015; 10: e0137864. [PubMed][CrossRef]

Publisert: 26. juni 2017. Tidsskr Nor Legeforen. DOI: 10.4045/tidsskr.17.0471

(C) Tidsskrift for Den norske legeforening 2020. Lastet ned fra tidsskriftet.no 